"Investment behavior of short-term versus long-term individual investors of PAN India - An empirical study"

\begin{tabular}{|c|c|}
\hline AUTHORS & Kannadas S. (D) \\
\hline ARTICLE INFO & $\begin{array}{l}\text { Kannadas S. (2021). Investment behavior of short-term versus long-term } \\
\text { individual investors of PAN India - An empirical study. Investment Management } \\
\text { and Financial Innovations, 18(2), 223-233. doi:10.21511/imfi.18(2).2021.18 }\end{array}$ \\
\hline DOI & http://dx.doi.org/10.21511/imfi.18(2).2021.18 \\
\hline RELEASED ON & Tuesday, 01 June 2021 \\
\hline RECEIVED ON & Tuesday, 20 April 2021 \\
\hline \multirow[t]{2}{*}{ ACCEPTED ON } & Wednesday, 26 May 2021 \\
\hline & 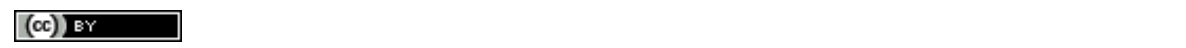 \\
\hline LICENSE & $\begin{array}{l}\text { This work is licensed under a Creative Commons Attribution } 4.0 \text { International } \\
\text { License }\end{array}$ \\
\hline JOURNAL & "Investment Management and Financial Innovations" \\
\hline ISSN PRINT & $1810-4967$ \\
\hline ISSN ONLINE & $1812-9358$ \\
\hline PUBLISHER & LLC “Consulting Publishing Company "Business Perspectives” \\
\hline FOUNDER & LLC “Consulting Publishing Company "Business Perspectives" \\
\hline
\end{tabular}

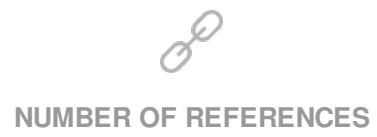

16

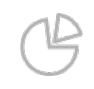

NUMBER OF FIGURES

0

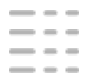

NUMBER OF TABLES

12

(C) The author(s) 2021. This publication is an open access article. 


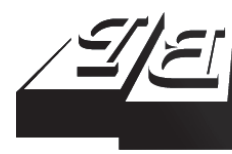

BUSINESS PERSPECTIVES

(O)

LLC "CPC "Business Perspectives" Hryhorii Skovoroda lane, 10 Sumy, 40022, Ukraine www.businessperspectives.org
Received on: $20^{\text {th }}$ of April, 2021 Accepted on: $26^{\text {th }}$ of May, 2021 Published on: $1^{\text {st }}$ of June, 2021

(c) Kannadas S., 2021

Kannadas S., MBA., M.Phil. (Ph.D.), Assistant Professor of Accounting \& Finance, SDM Institute for Management Development, India.

\section{INVESTMENT BEHAVIOR OF SHORT-TERM VERSUS LONG-TERM INDIVIDUAL INVESTORS OF PAN INDIA - AN EMPIRICAL STUDY}

\begin{abstract}
Investment activity, followed by household and external savings, often plays a decisive role in strengthening the financial status of individual investors, as it contributes to further increases in wealth. This study analyzes the investors' investment motives and actions to find better investment strategies and to do a systematic review of the investment behavior available for both short- and long-term individual investors. The study is mainly focused on factors and priorities influencing investment decisions. The data were obtained using the questionnaire approach from 201 individual investors within the age group from 18 to 80 from different parts of India. Every individual investor's risk-tolerant score has been calculated on the basis of the investors' holistic behavior, namely, investors with high-risk appetite, investors with a moderate and low-risk appetite. Non-parametric tests are applied to evaluate the behavioral approach of investors that are differently correlated to these factors. T-test is used to distinguish between the population mean of short-term and long-term investors' risk-taking ability and priority of safeguarding the principal over return preference, rather than identified investment factors. As a result of the study, the factors influencing the investors' decisions were found: income level, market participation experience and risk-return proportions, rather than age, gender, risk-taking ability and investment priority. This study enhances the existing literature by analyzing income, risk-return proportion and investment experience factors that influence investment decisions.
\end{abstract}

Keywords

individual investors, investment preference, risk tolerance

JEL Classification G11, G40, G41

\section{INTRODUCTION}

A condition that turns an emerging country into a developed nation is economic growth. In the Indian background, the new government is also focused on turning the Indian economy into a prosperous USD 5 trillion GDP by 2024 within the next five years. Most analysts believe that physical infrastructure, human resources, technologies and natural resources are typically influenced by financial inclusion. The contribution of each of these variables is crucial for a country's economic growth. Technology, which contributes to economic growth, is another aspect. Technological advancement makes workers more efficient and increases the economy's growth rate. Both these factors require a significant allocation of resources that comes from government funds. Central financing entities, such as the central bank, have these assets.

The Indian financial scene also provides investors with a wide range of opportunities irrespective of a kind of investments. While certainly not the best or deepest of the world's markets, a common person has reasonable options for investing his/her savings. It is an extension of economic growth. Current investment in the long term helps determine the future of the economy. By expanding personal income, in- 
vesting can contribute to increased overall economic growth and development. The short-term or longterm investment mechanism aims to build a financial system where people can collect money. This also leads to higher growth and stability in the economy.

Investments are primarily equity or primary wealth obligations of various owners for the acquisition of financial assets or instruments for the recovery of beneficial gains in terms of dividends, interest or appreciation, or the rise in the value of the financial assets in question. Investment choices made by individuals are on the basis of their attitudes, attitudes or ideological setup on the basis of the psychological strategy and their perspectives on investment visualize the actions of investment. The whole investment behavior system or mechanism involves the investment decisions of investors, their expectations, interpretation, procedures and evaluation of decision-making processes that encapsulate knowledge collection, identifying and understanding the entire market, conducting research on market options that may be productive in the near future, and making investments. Investment decisions are taken by individuals on the basis of their risk-bearing capacity, risk tolerance, return goals and need. In general, the decisions are on the basis of an interpretation of basic aspects, technological measures and investment period.

While certain intrinsic and extrinsic influences affect the investment decisions of both short-term and long-term investors, the factors influencing both investors' decisions are comparatively different from each other depending on various cognitive factors.

\section{LITERATURE REVIEW}

To embark on the objectives of this study, a review of earlier articles that concur with the focus of this study is done. The reviews are structured below on similar studies conducted earlier.

Murthi et al. (2012) highlighted that the investors' behavior while investing in various investment avenues. This study focuses on various investor actions to find the best investment prospects. Korniotis and Kumar (2011) investigated whether older investors make better investment decisions. According to the study, aged and experienced investors are more likely to obey "laws of thumb" that represent their greater investment awareness and experience. Older investors, on the other hand, are less successful in applying their investment skills and have lower investment ability, especially if the investors are less educated, earn a lower income. It was found in the study that the beneficial implications of experience are overshadowed by the adverse effects of ageing. The study concludes that older investors have more information about investing, their investment ability deteriorates as they get older due to the negative effects of cognitive ageing. Alquraan et al. (2016) added that few crucial demographic variables such as gender, age, income and experience do not make any significant transformations in the investor's decision, except the only variable education, which makes significant differences in the investor's decision. Metawa et al. (2019) attempted to prove that demographic variables such as age, gender and the level of education have substantial positive effects on the investment decisions of individual investors. According to the study, market experience does not play any key role in investment decisions, but as investors gain experience gradually due to continuous market participation, they tend to overlook the emotional factors irrespective of investment life.

Kartsova (2013) has explored factors forming Irrational Individual Investors' behavior. The aim of this paper is to identify the factors that lead to irrational individual investor behavior. Factors causing irrational behavior of individual investors were identified. The study describes cognitive factors such as self-confidence, experience and knowledge that influence the actions of individual investors and explain the logical relationship between those factors and the personal characteristics of individual investors. Bakar and Yi (2016) added that overconfidence of investors due to an illusion of having in-depth knowledge in the market and conservatism bias to safeguard the principal investment rather than focusing on returns significantly affect the investors' decision making 
and argued that the psychological factors depend on investors' gender. Kumar and Goyal (2016) concluded that gender and income level have a significant difference with respect to the investment decision-making process. Male investors are more persuaded to the overconfidence of investors.

Ngoc (2014) has investigated the cognitive factors affecting the decisions of individual investors. Individual investors have few crucial behavioral factors: herding, ability, overconfidence, anchoring-ability bias. Abdallah and Hilu (2015) have found that the exploring determinants explain the impact of the level of income, regularity of income of the individual investors on their financial behavior. According to the study, three likely independent variables that could predict investor risk attitude are investors' perceptions of information asymmetry, investor perceptions, and overconfidence. The study also shows factors affecting financial behavior and establish a common investment behavior. Warren (2014) has added the advantages and drawbacks of long-term investing over short-term investing. Long-term investors retain three main advantages: the opportunity to accept positions with unpredictable payment duration, the ability to profit from opportunities created by short-term investors' actions, and the ability to invest in non-listed properties and/or financial assets. These strengths the extent to which an organization investors access to a wider range of investment prospects than short-term investors can. Lee et al. (2015) did a comparative study of investor preferences among short-term investment versus long-term investment avenues. The study focused on investor expectations for short-and longterm investments. In financial terms, short-term investments are financial assets that are acquired with the intention of producing profits in the immediate future or being sold at a high-profit rate later. Henager-Greene and Cude (2016) have examined financial learning and financial awareness in different groups to see how different groups of people responded to financial literacy and financial existence. Three forms of financial knowledge were assessed: valuable financial details, moderate financial or self-confidence, and financial management skills. The focus of long-term financial activity is on saving for retirement and investment behavior, while short-term ethics refers to immediate spending. Raman et al. (2017) aimed to gain insights into the factors affecting the individual investors that need to consider improving their choice of investment. It was found that the factors like familiarity, confidence level and stages of life drive investors to choose the right avenue. Meanwhile, Yuniningsih et al. (2017) tried to test the level of risk that the investors are willing to take during their investment associated with the loss aversion and found that the loss aversion has a significant influence on the risk-taking ability while making an investment decision. Arianti (2018) revealed that financial literacy has no significant effect, but income behavior has a significant effect on the investment decisions of the investors.

After the critical literature review, a wide scope for further research has been found. Based on the scope identified, an attempt is made in this study to identify and analyze a few aspects in the investors' investment behavior by comparing shortterm and long-term investments concerning the impact of their age, gender, income level, market participation and experience on investment decisions.

\section{AIMS}

The study aims to assess the effect of psychological aspects on employed short-term and long-term investors' investment decisions. This study further seeks to define and analyze the variables affecting investor actions during the investment decision-making process, as well as to comprehend behavioral aspects and multiple forms of prejudices that influence an individual's decision-making process.

\section{METHODOLOGY}

This study consists of both primary and secondary data. This is an exploratory study, and the information on the investor's preference was collected through a questionnaire survey.

The primary data were collected by providing a questionnaire to small and medium scale business individuals who spread across various cities in India. Secondary data were collected by referring to various articles, journals, research papers, magazines, and newspapers. The sample size un- 
der this study is 201 respondents of metro cities of PAN India. The method of sampling applied here is selective random sampling. To analyze the behavioral difference between short-term and longterm investors, the following tests were applied on the scientifically arrived sample size for this study.

Primarily, Chi-Square Test is applied, which is a statistical test for determining whether a hypothesis is true. In one or more groups, the chi-squared test is used to assess if there is a substantial difference between predicted and observed frequencies of the extracted factors among short-term and long-term investors such as age, gender, income level, risk appetite, investment priority, advisor and market participation. Secondly, T-Test analysis and interpretation of various factors are applied. T-tests are hypothesis tests that compare two or more groups' means. Hypothesis tests are used to infer properties of whole populations from sample data. After arriving at a required sample from the target populations, the test is applied to decide whether it is true that two group means are different, Paired means are different and one mean is different from a target value. The means of exactly two groups are compared in two-sample $t$-tests - no more, no less! This test is usually used to see if the means of two populations are different. Here it is applied to test the difference in risk taking ability and prioritizing principal investment safety over the return on investment.

\section{RESULTS}

a) Objective of the test - To find the impact of gender on short and long-term investment.

Null Hypothesis: There is no impact of gender on short and long-term investment.

Alternate Hypothesis: There is an impact of gender on short and long-term investment.

Table 1. Expected frequencies of the impact of gender on short and long-term investment

\begin{tabular}{c|c|c|c}
\hline Gender & Long-term & Short-term & Grand total \\
\hline Female & 38.059701 & 36.9402985 & 75 \\
\hdashline Male & 63.940299 & 62.0597015 & 126 \\
\hline Grand total & 102 & 99 & 201 \\
\hline
\end{tabular}

Note: $p$-value $=0.07710891$.

\section{Result interpretation}

The test is conducted to check the association/ impact of gender on the ability to invest in the short and long term while investing at a significance level of 5\% and a level of confidence of $95 \%$. The $p$-value is $0.07710 p$-value $>0.05$, therefore, the Null Hypothesis is accepted, and the Alternate Hypothesis is rejected. Therefore, there is no significant impact of gender on the ability to invest as the investment is not done for specific gender requirement but for wealth creation and maximization.

b) Objective of the test - To find the impact of age on the ability to take risk in the short and long term while investing.

Null Hypothesis: There is no impact of age on the ability to take risk while investing.

Alternate Hypothesis: There is an impact of age on the ability to take risk while investing.

Table 2. Expected frequencies of impact of age on the ability to take risk in the short and long term while investing.

\begin{tabular}{c|c|c|c}
\hline \multicolumn{1}{c}{ Age range } & Long-term & Short-term & Grand total \\
\hline $0-30$ Years & 88.80597015 & 86.1940299 & 175 \\
\hline $30-45$ Years & 10.14925373 & 9.85074627 & 20 \\
\hdashline $45-60$ Years & 3.044776119 & 2.95522388 & 6 \\
\hdashline Grand total & 102 & 99 & 201 \\
\hline
\end{tabular}

Note: $p$-value $=0.16303826$

\section{Result interpretation}

The test is conducted to check the association/impact of age on the ability to take risk in the short and long term while investing at a significance level of $5 \%$ and a level of confidence at $95 \%$. The $p$-value is 0.16303 i.e., $p$-value $>0.05$, therefore the Null Hypothesis is accepted and the Alternate Hypothesis is rejected. Thus, there is no significant impact of age on the ability to take risk while investing as the type of investing is based on their requirements.

c) Objective of the test - To find the impact of income on the type of short and long-term investment. 
Null Hypothesis: There is no impact of income on the level of investment while investing in the short and long term.

Alternate Hypothesis: There is an impact of income on the level of investment while investing in the short and long term.

Table 3. Expected frequencies of the impact of income on the level of investment while investing in the short and long term

\begin{tabular}{l|c|c|c}
\hline \multicolumn{1}{c|}{ Income level } & $\begin{array}{c}\text { Long- } \\
\text { term }\end{array}$ & Short-term & $\begin{array}{c}\text { Grand } \\
\text { total }\end{array}$ \\
\hline ₹ 2,00,000 to ₹ 6,00,000 & 34.183784 & 33.8162162 & 68 \\
\hdashline ₹ $6,00,000$ to ₹ 10,00,000 & 12.064865 & 11.9351351 & 24 \\
\hdashline Above ₹ 10,00,000 & 5.5297297 & 5.47027027 & 11 \\
\hline Below ₹ 2,00,000 & 41.221622 & 40.7783784 & 82 \\
\hline Grand total & 93 & 92 & 185 \\
\hline
\end{tabular}

Note: $p$-value $=0.03668166$

\section{Result interpretation}

The test is conducted to check the association/impact of income on the level of investing at a significance level of $5 \%$ and level of confidence at $5 \%$. $P$-value $<0.05$, therefore the Null Hypothesis is rejected and the Alternate Hypothesis is accepted. Thus, there is an impact of income on the level of investing as the type of investment is based on the specific financial requirements (either short-term or long-term) of investors. If the investors are regular interval earners like salaried or fixed periodic income gainers, they plan their investment portfolio accordingly. On the other hand, if the investor is a businessman or irregular income gainer, their investment portfolio will be different.

d) O bjective of the test - To find the impact of an advisor on the short and long-term investor opinion or investment behavior.

Null Hypothesis: There is no impact of an advisor on the short and long-term investor opinion or investment behavior.

Alternate Hypothesis: There is an impact of an advisor on short and long-term investor opinion or investment behavior.
Table 4. Expected frequencies of the impact of an advisor on short and long-term investor opinion or investment behavior

\begin{tabular}{l|c|c|c}
\hline $\begin{array}{c}\text { Financial } \\
\text { advisor aid }\end{array}$ & Long-term & Short-term & $\begin{array}{c}\text { Grand } \\
\text { total }\end{array}$ \\
\hline No & 75.61194 & 73.3880597 & 149 \\
\hline Yes & 26.38806 & 25.6119403 & 52 \\
\hline Grand total & 102 & 99 & 201 \\
\hline
\end{tabular}

Note: $p$-value $=0.84371233$.

\section{Result interpretation}

The test is conducted to check the association/ impact of a financial advisor on investment behavior at a significance level of 5\% and level of confidence at $95 \%$. $P$-value $>0.05$, therefore the Null Hypothesis is accepted and the Alternate Hypothesis is rejected. Thus, there is no impact of a financial advisor on investment behavior.

e) Objective of the test - To find the priority of investing between short and long-term investors.

Null Hypothesis: There is no significant impact of investment priority between short and long-term investors.

Alternate Hypothesis: There is a significant impact of investment priority between short and long-term investors.

Table 5. Expected frequencies of the impact of investment priority between short and longterm investors

\begin{tabular}{l|c|c|c}
\hline \multicolumn{1}{c}{ Purpose } & Long-term & $\begin{array}{c}\text { Short- } \\
\text { term }\end{array}$ & $\begin{array}{c}\text { Grand } \\
\text { total }\end{array}$ \\
\hline Earn Returns & 24.865672 & 24.1343284 & 49 \\
\hline $\begin{array}{l}\text { Future Requirements } \\
\text { Huge Tax-Saving }\end{array}$ & 26.895522 & 26.1044776 & 53 \\
\hline Not to keep the money & 14.208955 & 13.7910448 & 28 \\
idle & 0.5074627 & 0.49253731 & 1 \\
\hline Wealth Creation & 35.522388 & 34.4776119 & 70 \\
\hline Grand total & 102 & 99 & 201 \\
\hline
\end{tabular}

Note: $p$-value $=0.10782783$.

\section{Result interpretation}

The test is conducted to check the association/impact of priority of investing between short and long-term investors at a significance level of 5\% and level of confidence at $95 \%$. $P$-value $>0.05$, 
therefore, the Null Hypothesis is accepted and the Alternate Hypothesis is rejected. Therefore, there is no significant impact of investment priority between short and long-term investors.

f) Objective of the test - To find the impact of the years of market participation on investment of short and long-term investors.

Null Hypothesis: There is no impact of the years of market participation on investment of short and long-term investors.

Alternate Hypothesis: There is an impact of the years of market participation on investment of short and long-term investors.

Table 6. Expected frequencies of the impact of the years of market participation on investment of short and long-term investors

\begin{tabular}{l|c|c|c}
\hline Market participant & Long-term & Short-term & $\begin{array}{c}\text { Grand } \\
\text { total }\end{array}$ \\
\hline$<1$ year & 52.776119 & 51.2238806 & 104 \\
\hline $1-3$ years & 36.537313 & 35.4626866 & 72 \\
\hline $3-5$ years & 6.5970149 & 6.40298507 & 13 \\
\hline More than 5 years & 6.0895522 & 5.91044776 & 12 \\
\hline Grand total & 102 & $99 . .$. \\
\hline
\end{tabular}

Note: $p$-value $=0.00983512$

\section{Result interpretation}

The test is conducted to check the association/impact of the years of market participants on their investment of short and long-term investors at a significance level of $5 \%$ and level of confidence at $95 \%$. $P$-value $<0.05$, therefore, the Null Hypothesis is rejected and the Alternate Hypothesis is accepted. Therefore, there is an impact of the years of market participation on investment of short and long-term investors. As gradually investors develop self-confidence on their investment decisions based on their experience, their market participation will have a huge impact on their investment decisions.

g) Objective of the test - To find the impact of taking different levels of risk on the investment of short and long-term investors.
Null Hypothesis: There is no impact of taking different levels of risk on the investment of short and long-term investors.

Alternate Hypothesis: There is an impact of taking different levels of risk on the investment of short and long-term investors.

Table 7. Expected frequencies of the impact of taking different levels of risk on the investment of short and long-term investors

\begin{tabular}{|c|c|c|c|}
\hline Risk level & Long-term & Short-term & Grand total \\
\hline Large & 19.283582 & 18.7164179 & 38 \\
\hline Medium & 52.776119 & 51.2238806 & 104 \\
\hline Small & 16.746269 & 16.2537313 & 33 \\
\hline Very small & 13.19403 & 12.8059701 & 26 \\
\hline Grand total & 102 & 99 & 201 \\
\hline
\end{tabular}

Note: $p$-value $=0.11936439$.

\section{Result interpretation}

The test is conducted to check the association/impact of taking different levels of risk on the investment of short and long-term investors at a significance level of $5 \%$ and level of confidence at $95 \%$. $P$-value $>0.05$, therefore the Null Hypothesis is accepted and the Alternate Hypothesis is rejected. Therefore, there is no impact of taking different levels of risk on the investment of short and longterm investors.

h) Objective of the test - To find the impact of risk and return factors considered before investment on the decisions of short and longterm investors.

Null Hypothesis: There is no impact of risk and return factors considered before investment on the decisions of short and long-term investors.

Alternate Hypothesis: There is an impact of risk and return factors considered before investment on the decisions of short and long-term investors. 
Table 8. Expected frequencies of the impact of risk and return factors considered before investment on the decisions of short and longterm investors

\begin{tabular}{|c|c|c|c|}
\hline $\begin{array}{l}\text { Factors considered } \\
\text { before investment }\end{array}$ & Long-term & Short-term & $\begin{array}{c}\text { Grand } \\
\text { total }\end{array}$ \\
\hline $\begin{array}{l}\text { High returns and High } \\
\text { Risks }\end{array}$ & 19.791045 & 19.2089552 & 39 \\
\hline $\begin{array}{l}\text { Low risk and Low } \\
\text { Return }\end{array}$ & 17.253731 & 16.7462687 & 34 \\
\hline Many... Actually & 0.5074627 & 0.49253731 & 1 \\
\hline Quick Maturity period & 9.1343284 & 8.86567164 & 18 \\
\hline Safety of principal & 54.80597 & 53.1940299 & 108 \\
\hline (blank) & 0.5074627 & 0.49253731 & 1 \\
\hline Grand total & 102 & 99 & 201 \\
\hline
\end{tabular}

Note: $p$-value $=0.46489786$

\section{Result interpretation}

The test is conducted to check the association/ impact of factors considered before investment on the decisions of short and long-term investors at a significance level of $5 \%$ and level of confidence at $95 \%$. $P$-value $>0.05$, therefore the Null Hypothesis is accepted and the Alternate Hypothesis is reject. Therefore, there is an impact of risk and return factors considered before investment on the decisions of short and long-term investors. Regardless of the type of investment, investors prefer investment safety over huge returns. This indicates the conservative mindset of investors.

\section{T-test}

\section{T-test with equal variances}

a) Objective of the test - To understand the difference in the risk-taking ability among short-term and long-term investors.

Null Hypothesis: The two-population means are equal for risk-taking ability among short-term and long-term investors.

Alternative Hypothesis: The two-population means are not equal for risk-taking ability among shortterm and long-term investors.
Table 9. $t$-test: Two-sample assuming equal variances

\begin{tabular}{|c|c|c|}
\hline Particulars & Short-term & Long-term \\
\hline Mean & 2.696969697 & 2.803921569 \\
\hline Variance & 1.070500928 & 0.733449816 \\
\hline Observations & 99 & 102 \\
\hline Pooled Variance & 0.899434785 & - \\
\hline $\begin{array}{l}\text { Hypothesized Mean } \\
\text { Difference }\end{array}$ & 0 & - \\
\hline df & 199 & - \\
\hline$t$ Stat & -0.799324645 & - \\
\hline$P(T<=t)$ one-tail & 0.212527613 & - \\
\hline$t$ Critical one-tail & 1.652546746 & - \\
\hline$P(T<=t)$ two-tail & 0.425055226 & - \\
\hline$t$ Critical two-tail & 1.971956544 & - \\
\hline
\end{tabular}

\section{Result interpretation}

The output indicates that the mean for Method A is 2.69 , and for Method B it is 2.80. Looking at the Variances row, they are not exactly equal, but they are close enough to assume equal variances.

For the results, $P(T<=\mathrm{t})$ two-tail is used, which is the $\mathrm{p}$-value for the two-tailed form of the $t$-test. Because the p-value (0.425055226) is greater than the standard significance level of 0.05 , null hypothesis can be accepted, and the alternative hypothesis can be rejected. This means that the two-population means are equal for risk-taking ability among short-term and long-term investors. So, it is found that there is no difference in the risk-taking ability of short-term and long-term investors as their motive of investment is different based on their requirements.

b) Objective of the test - To understand the safety of principal investment over returns among short-term vs. long-term investors.

Null Hypothesis: The two-population means are equal for the safety of principal investment over returns among short-term vs long-term investors.

Alternative Hypothesis: The two-population means are not equal for the safety of principal investment over returns among short-term vs long-term investors. 
Table 10. $t$-test: Two-sample assuming equal variances

\begin{tabular}{|c|c|c|}
\hline Particulars & Short-term & Long-term \\
\hline Mean & 3.878787879 & 3.833333333 \\
\hline Variance & 0.821892393 & 0.892739274 \\
\hline Observations & 99 & 102 \\
\hline Pooled Variance & 0.857849855 & - \\
\hline $\begin{array}{l}\text { Hypothesized Mean } \\
\text { Difference }\end{array}$ & 0 & - \\
\hline df & 199 & - \\
\hline t Stat & 0.347849459 & - \\
\hline$P(T<=t)$ one-tail & 0.364160452 & - \\
\hline t Critical one-tail & 1.652546746 & - \\
\hline$P(T<=t)$ two-tail & 0.728320904 & - \\
\hline$t$ Critical two-tail & 1.971956544 & - \\
\hline
\end{tabular}

\section{Result interpretation}

The output indicates that the mean for short-term investors is 3.878787879 and for long-term investors is 3.833333333. Looking in the Variances row, they are not exactly equal, but they are close enough to assume equal variances.

For the results, $P(T<=t)$ two-tail is used, which is the $\mathrm{p}$-value for the two-tailed form of the $t$-test. Because the $p$-value (0.728320904) is greater than the standard significance level of 0.05 , the null hypothesis can be accepted, and the alternative hypothesis can be rejected. This means that the two-population means are equal for the safety of the principal over returns among short-term versus long-term investors. It has been established that irrespective of the type of investors, be it short-term or long-term investors, their concern for the safety of principal investment over the returns is of top priority.

\section{CONCLUSION}

The study found that the majority of aged investor respondents do not have a financial advisor, may be because they believe in their own understanding of the investment market in short- and long-term investment avenues.

It was also found that the reason for investing in the market can be wealth creation, future requirements and earn returns and, the frequency of checking their security performance is week because most respondents do agree with that.

The study found that $74 \%$ of respondents have chosen to stay with the investment, which has greater returns, instead of going by unknown investment, which has unpredictable challenges. Notably, $40 \%$ of respondents have chosen the financial and procurement sector to invest in the short and long term, and $51 \%$ of respondents have chosen to focus on the price fluctuation of the stock in which they want to invest.

It was also found that most respondents have chosen to go for the best possible return even if there is a considerable risk involved, and $53 \%$ of respondents consider the factor of safety of principal before investing in the market.

Statistical analysis showed no considerable impact of the gender difference on the ability to invest, irrespective of the kind of investment, as self-confidence and earning capacity are their major strength. There is a significant impact of income level and rate of income on their investment decisions and earning from those investments, respectively.

The study found that, irrespective of the type of investors, be it short-term or long-term investors, their concern on the safety of principal investment over the returns is of top priority. 
Short-term and long-term investments of individual investors contribute to various requirements at various stages of their lives. Based on the findings, it is concluded that there is a huge impact of market participation and experience with the confidence of having in-depth knowledge on investment decisions rather than the investors with lesser market participation and knowledge. Based on the findings, it can be also concluded that though each and every investor have their own priorities and expectations on their investments at various stages of their life, there is a crucial role played by their income levels and the risk-return proportions against the prospective investments on their investment decisions. The findings also suggest that further research on the behavioral finance impact on investment decisions could benefit by including the individual personality of market participants as a vital explanatory factor.

This paper has some limitations, since the study is limited only to a sample of 201 respondents.

The views of the respondents are subject to their bias and prejudice. The findings of this study are based on sample size and cannot be generalized. The research period is very limited. Hence, time constraints could be a limiting factor.

\section{AUTHOR CONTRIBUTIONS}

Conceptualization: Kannadas S.

Data curation: Kannadas S.

Formal analysis: Kannadas S.

Investigation: Kannadas S.

Methodology: Kannadas S.

Project administration: Kannadas S.

Supervision: Kannadas S.

Validation: Kannadas S.

Visualization: Kannadas S.

Writing - original draft: Kannadas S.

Writing - review \& editing: Kannadas S.

\section{REFERENCES}

1. Abdallah, S., \& Hilu, K. (2015).

Exploring Determinants to Explain Aspects of Individual Investors' Financial Behaviour. Australasian Accounting, Business and Finance Journal, 4-22. http:// dx.doi.org/10.14453/aabff.v9i2.2

2. Alquraan, T., Alqisie, A., \& Shorafa, A. A. (2016). Do Behavioral Finance Factors Influence Stock Investment Decisions of Individual Investors? (Evidences from Saudi Stock Market). American International Journal of Contemporary Research, 159-169. Retrieved from http:// www.aijcrnet.com/journals/Vol_6 No_3_June_2016/16.pdf

3. Arianti, B. F. (2018). The influence of financial literacy, financial behavior and income on investment decision. Economics and Accounting Journal, 1-10. Retreived from http://www.openjournal.unpam.ac.id/index.php/ EAJ/article/viewFile/1277/1014

4. Bakar, S., \& Yi, A. N. (2016). The Impact of Psychological Factors on Investors' Decision Making in Malaysian Stock Market: A Case of Klang Valley and Pahang. Procedia Economics and Finance, 319-328. https://doi.org/10.1016/ S2212-5671(16)00040-X

5. Henager-Greene, R., \& Cude, B. (2016). Financial Literacy and Long- and Short-Term Financial Behavior in Different Age Groups. Journal of Financial Counseling and Planning, 3-19. Retreived from https://files.eric.ed.gov/fulltext/EJ1161904.pdf
6. Kartsova, J. (2013). Factors forming irrational Lithuanian individual investors' behaviour. Business systems and economics, 69-78. Retreived from https:// repository.mruni.eu/bitstream/ handle/007/10555/311-495-1-SM. pdf? sequence $=1$

7. Korniotis, G. M., \& Kumar, A. (2011). Do Older Investors Make Better Investment Decisions? The Review of Economics and Statistics, 244-265. Retreived form https://direct.mit.edu/rest/ article/93/1/244/57885/Do-OlderInvestors-Make-Better-Investment

8. Kumar, S., \& Goyal, N. (2016). Evidence on rationality and behavioural biases in investment decision making. Qualitative Research in Financial Markets, 8(4), 
270-287. https://doi.org/10.1108/ QRFM-05-2016-0016

9. Lee, Y.-J., Wang, G.-L., Kao, K.-S., Chen, C.-Y., \& Zhu, F.-P. (2015). The investment behavior, decision factors and their effects toward investment performance in the Taiwan stock market. The Journal of Global Business Management, 179-190. Retreived from https://www.proquest.com/ openview/95c74243cf58cd8d bce $57 \mathrm{~d} 35 \mathrm{c} 802 \mathrm{fb} 21 / 1$.pdf?pqorigsite $=$ gscholar\&cbl $=406316$

10. Metawa, N., Hassan, M. K., Metawa, S., \& Safa, S. (2019). Impact of behavioral factors on investors' financial decisions: case of the Egyptian stock market. International Journal of Islamic and Middle Eastern Finance and Management, 30-55. http://dx.doi.org/10.1108/IMEFM-12-2017-0333
11. Murthi, S., Narayanan, B., \& Arivazhagan, M. (2012). Investors behaviour in various investment avenues. International Journal of Marketing and Technology, 164-189. Retreived from https:// www.semanticscholar.org/paper/ Investors-behaviour-in-variousinvestment-avenues- $\% \mathrm{E} 2 \% 80 \% 93$ Murithi-Narayanan/420elbc8f3fd 2e6d38a33ad088f5535fa1e0939a

12. Ngoc, L. T. (2014). Behavior Pattern of Individual Investors in Stock Market. International Journal of Business and Management, 1-16. https://doi. org/10.5539/ijbm.v9n1p1

13. Oehler, A., Wendt, S., Wedlich, F., \& Horn, M. (2018). Investors' Personality Influences Investment Decisions: Experimental Evidence on Extraversion and Neuroticism. Journal of Behavioral Finance, 3048. https://doi.org/10.1080/154275 60.2017.1366495
14. Raman, S., Niranjan, I., Patwa, N., \& Kejriwal, A. (2017). A Study of the Factors Affecting the Choice of Investment Portfolio by Individual Investors in Singapore. Accounting and Finance Research, 153-168. https://doi.org/10.5430/ afr.v6n3P153

15. Warren, D. G. (2014). Benefits (and Pitfalls) of Long-Term Investing. Sydney: Centre for International Finance and Regulation. Retrieved from https://apo.org.au/sites/default/ files/resource-files/2014-10/aponid65893.pdf

16. Yuniningsih, Y., Widodo, S., \& Wajdi, B. N. (2017). An analysis of Decision Making in the Stock Investment. Jurnal Ekonomi dan Hukum Islam, 123-129. Retreived from http://ejournal.kopertais4. or.id/tapalkuda/index.php/economic/article/view/2987/2199 


\section{APPENDIX A. RESPONDENTS' PROFILE}

Table A1. Classification of investors

\begin{tabular}{|c|c|c|c|c|c|c|c|}
\hline \multirow{2}{*}{ Particulars } & \multicolumn{3}{|c|}{ Long-term investors } & \multicolumn{3}{|c|}{ Short-term investors } & \multirow{2}{*}{ Total } \\
\hline & Female & Male & Total & Female & Male & Total & \\
\hline Salaried & 15 & 36 & 51 & 10 & 25 & 35 & 86 \\
\hline$<1$ year & 8 & 13 & 21 & 9 & 14 & 23 & 44 \\
\hline $1-3$ years & 6 & 15 & 21 & 1 & 8 & 9 & 30 \\
\hline $3-5$ years & 1 & 1 & 2 & - & 2 & 2 & 4 \\
\hline More than 5 years & - & 7 & 7 & - & 1 & 1 & 8 \\
\hline Self-Employed & 5 & 9 & 14 & 7 & 5 & 12 & 26 \\
\hline$<1$ year & 1 & 1 & 2 & 3 & 2 & 5 & 7 \\
\hline $1-3$ years & 3 & 5 & 8 & 2 & 2 & 4 & 12 \\
\hline $3-5$ years & 1 & 1 & 2 & 2 & - & 2 & 4 \\
\hline More than 5 years & - & 2 & 2 & - & 1 & 1 & 3 \\
\hline Student & 12 & 25 & 37 & 26 & 26 & 52 & 89 \\
\hline$<1$ year & 6 & 13 & 19 & 20 & 14 & 34 & 53 \\
\hline $1-3$ years & 5 & 11 & 16 & 5 & 9 & 14 & 30 \\
\hline $3-5$ years & 1 & 1 & 2 & - & 3 & 3 & 5 \\
\hline More than 5 years & - & - & - & 1 & - & 1 & 1 \\
\hline Grand total & 32 & 70 & 102 & 43 & 56 & 99 & 201 \\
\hline
\end{tabular}

Table A2. Classification of investors based on growth expectations

\begin{tabular}{|c|c|c|c|c|c|c|c|}
\hline \multirow{2}{*}{ Particulars } & \multicolumn{3}{|c|}{ Long-term investors } & \multicolumn{3}{|c|}{ Short-term investors } & \multirow{2}{*}{ Tota } \\
\hline & Female & Male & Total & Female & Male & Total & \\
\hline Growth and Income & 11 & 18 & 29 & 15 & 17 & 32 & 61 \\
\hline$<1$ Year & 6 & 6 & 12 & 10 & 10 & 20 & 32 \\
\hline$>5$ Years & - & 1 & 1 & - & 1 & 1 & 2 \\
\hline $0-3$ Years & - & - & & 1 & - & 1 & 1 \\
\hline $1-3$ Years & 3 & 7 & 10 & 3 & 5 & 8 & 18 \\
\hline $3-5$ Years & 2 & 4 & 6 & 1 & - & 1 & 7 \\
\hline (blank) & - & - & - & - & 1 & 1 & 1 \\
\hline Income and Capital Preservation & 1 & 6 & 7 & 9 & 8 & 17 & 24 \\
\hline$<1$ Year & - & 3 & 3 & 5 & 2 & 7 & 10 \\
\hline$>5$ Years & - & 1 & 1 & - & 1 & 1 & 2 \\
\hline $0-3$ Years & 1 & 2 & 3 & - & 2 & 2 & 5 \\
\hline $1-3$ Years & - & - & - & 2 & 2 & 4 & 4 \\
\hline $3-5$ Years & - & - & - & 1 & 1 & 2 & 2 \\
\hline (blank) & - & - & - & 1 & - & 1 & 1 \\
\hline Long term growth & 15 & 37 & 52 & 10 & 20 & 30 & 82 \\
\hline$<1$ Year & 7 & 16 & 23 & 6 & 14 & 20 & 43 \\
\hline$>5$ Years & 1 & 7 & 8 & - & - & - & 8 \\
\hline $0-3$ Years & - & 2 & 2 & 1 & 3 & 4 & 6 \\
\hline $1-3$ Years & 6 & 11 & 17 & 3 & 3 & 6 & 23 \\
\hline $3-5$ Years & 1 & 1 & 2 & - & - & - & 2 \\
\hline Short term growth & 5 & 9 & 14 & 9 & 10 & 19 & 33 \\
\hline$<1$ Year & 1 & - & 1 & 5 & 1 & 6 & 7 \\
\hline$>5$ Years & - & 1 & 1 & - & - & - & 1 \\
\hline $1-3$ Years & 4 & 6 & 10 & 4 & 9 & 13 & 23 \\
\hline $3-5$ Years & - & 2 & 2 & - & - & - & 2 \\
\hline (blank) & - & - & - & - & 1 & 1 & 1 \\
\hline$<1$ Year & - & - & - & - & 1 & 1 & 1 \\
\hline (blank) & - & - & - & - & - & - & - \\
\hline Grand total & 32 & 70 & 102 & 43 & 56 & 99 & 201 \\
\hline
\end{tabular}

